\title{
Local Production for Local Consumption and Improvement Performance of Construction Materials
}

by

\author{
Hidenobu TOKUSHIGE*
}

私が所属する秋田大学大学院理工学研究科 (理工学部) は，2014年に旧工学資源学部から改組に伴い設立されま した. 旧工学資源学部は1998年に設立された学部です が，私が赴任した1996年当時は改組前の鉱山学部であ り，1910年に設置された秋田鉱山専門学校が基となって います．現在の秋田大学は教育文化学部，医学部，国際 資源学部そして理工学部の 4 学部から構成されており, 県内外〜国外の幅広い地域の学生が学んでいます。一方, 近年の秋田県は人口減少率が $1.41 \%$ と国内 1 位（都道府 県別，2018年1月現在，総務省調査）加高齢化率も $35.6 \%$ と国内 1 位（都道府県別, 2017年現在, 内閣府調査) であり, 少子高齢・人口減少の最先端地域であるとも言 えます.かつての秋田県は鉱山需要で賑わっていたこと から地方産業の集積もありましたが，秋田大学における 鉱山専門学校から理工学部と国際資源学部に至る歴史 も，地域の事情の変遷を表していると思います。このよ うなことを背景として, 特に最近は, Sustainable Development Goals（持続可能な開発目標, SDGs) を念 頭に, 地域に如何に貢献していくのかが地方国立大学の 役目として強まっており, 地域の事情も念頭におきなが ら, 土木工学のコンクリート工学を専門として研究・教 育に取り組んでいるところです。

地産地消という言葉は農林水産事業関連でよく用いら れる用語ですが, 建設材料では石材や土質材料, 木質系 材料をはじめとして（もちろんローマン・コンクリー トをはじめとして）「地産地消」で賄われているものが 古くから数多くあります. 流通が高度化した近年では, コンクリート原材料に対して「地産もの」を用いるのは, 品質の確保という点からも多くない状況にあります。特 に骨材については品質の確保と輸送費の増大など，様々 な課題を抱えている状況にあります.

私が現在取り組んでいる研究テーマのひとつとして, コンクリート用材料にあらためて地産地消をキーワード としたものを積極的に取り入れて，コンクリートの品質 と性能の確保を行うことを目的としているものがありま す。秋田県には良質の石炭灰を排出する火力発電所があ り, この石炭灰（フライアッシュ）を県内で有効に利用 するのは，まさに地産地消にかなっています．積雪寒冷 地であり, 沿岸部は日本海からの冬期の飛来塩分 $(\mathrm{NaCl})$, 内陸部は凍結防止剂 (凍結抑制剂) として散布される岩 塩 $(\mathrm{NaCl})$ に曝される秋田のコンクリート構造物は, 凍 害や塩害とその複合劣化, さらに近年話題の遅延型アル
カリシリカ (ASR) 反応性骨材による劣化に対する措置 が重要です。これらの措置に対して，ポゾラン材料であ るフライアッシュを混和材として用いることは, 地産地 消, かつコンクリートの性能確保・向上に有効であり, 近年，特に硬化コンクリートの耐久性に及ぼす配合の検 討を行っているところです。 また東北地方全体では，製 紙工場から排出される加熱改質フライアッシュについて も, 広い意味での地産地消材料であり, 配合設計の検討 を行っています。なおフライアッシュの利活用について は, 日本材料学会誌「材料」の記事もこれまで数多く参 考にさせて頂いています。

一方，私の博論が（ポーラスコンクリートを主体とし た）透水性コンクリートの配合設計と凍害劣化機構に関 するものでもあり，これまで取り組んでいる研究テーマ のひとつに，ポーラスコンクリートの高機能化がありま す． 近年ではこの高機能化のひとつとして，サンゴ育成 基盤への応用についての検討を行っています。この基盤 の配合設計には，会誌「材料」に共著者として過去に掲 載された酸化チタン混和モルタルに関する内容も応用し ています。サンゴ育成基盤の開発には，セメントコンク リート分野の他研究者はもちろんですが, 金属材料の知 見を基にインプラント等の生体材料を専門とする研究者 や流力発電技術を有する研究者, 民間の方々との連携で 行っています。研究室内試験と試験設置を繰返し, 失敗 を繰返しながら進めているところです。

日本材料学会は「材料」に関する幅広い分野の研究者が 参画されている場であり, 情報交換をさせていただきなが ら, 研究・教育と地域貢献を進められれば, と思うところ です．今後ともどうぞよろしくお願い申し上げます。

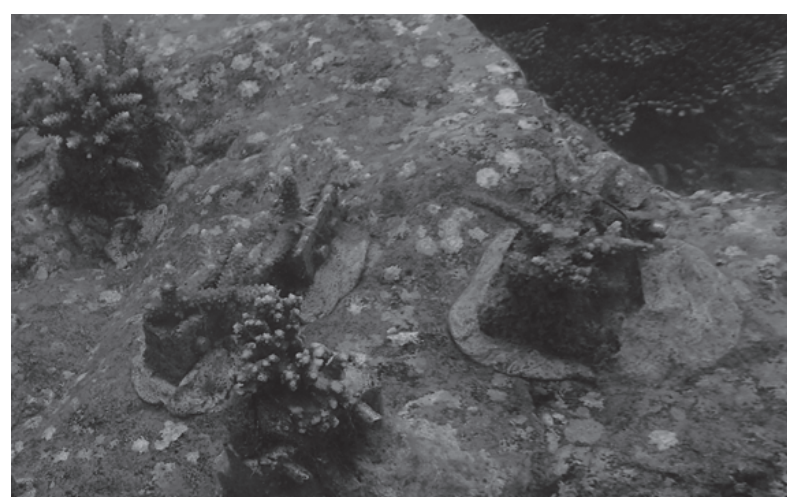

図 1 ポーラスモルタルを用いたサンゴ再生基盤の設置例

原稿受理 平成 31 年 4 月 1 日 Received Apr. 1, 2019 @2019 The Society of Materials Science, Japan

* 正会員 秋田大学大学院理工学研究科システムデザイン工学専攻 † 010-8502 秋田市手形学園町, Dept. of Systems Design Eng., Akita Univ., Tegata Gakuen-machi, Akita, 010-8502 